\title{
Exploring biofertilizer potential of plant growth-promoting rhizobacteria candidates from different plant ecosystems
}

\author{
DWI AGUSTIYANI", TIRTA KUMALA DEWI, NUR LAILI, ACHIRUL NDITASARI, SARJIYA ANTONIUS \\ Research Centre for Biology, Indonesian Institute of Sciences. Jl. Raya Bogor-Jakarta Km. 46, Cibinong, Bogor 16911, West Java, Indonesia. \\ Tel.: +62-21-87907612, Fax.: +62-21-87907612, "email: titinagustin@yahoo.com
}

Manuscript received: 30 January 2021. Revision accepted: 20 April 2021

\begin{abstract}
Agustiyani D, Dewi TK, Laili N, Nditasari A, Antonius S. 2021. Exploring biofertilizer potential of plant growth-promoting rhizobacteria candidates from different plant ecosystems. Biodiversitas 22: 2691-2698. Plant growth-promoting rhizobacteria (PGPR) have been widely used as inoculants to increase the growth of crops. This study aims to evaluate the effective PGPR strains according to their capability in various plant growth-promoting activities in vitro. Ten rhizosphere soil samples were obtained from several plant ecosystems in Bangkinang, Kampar, Sumatra Island, Indonesia. A total of 42 bacteria were isolated and tested for three plant growthpromoting activities i.e., phosphate solubilization, indole-3-acetic acid (IAA) production, and $\mathrm{N}$ fixation. Out of 42 isolates, 26 were positive for phosphate solubilization, 11 were positive for IAA production, and five were positive for $\mathrm{N}$ fixation. The qualitative and quantitative analysis of plant growth-promoting activities revealed that the highest phosphate solubilizing isolate was PK.4.2 (SI 4.33); the highest IAA-producing isolate was I.4.2 (73.1 ppm); while the highest N-fixing ability was NFB.1.1. According to the seed bioassay results, the shoot and root length of bok choy (Brassica rapa) seedlings were significantly enhanced with the PGPR isolates treatment. The highest shoot length $(2.53 \mathrm{~cm})$ was observed among seeds treated with I.4.2 isolate, followed by PK.6.1 (2.45 cm) and I.5.3 (2.07 $\mathrm{cm})$. The NFB.1.1 isolate promoted the longest root length $(6.4 \mathrm{~cm})$, although this was similar with I.5.3 isolate $(6.11 \mathrm{~cm})$. Two isolates that showed significant plant growth-promoting activities were analyzed using 16S rDNA sequences. The two isolates had a close evolutionary relationship with genus Sinomonas strain Cw 108 (I.4.2) and Arthrobacter (I.5.3.).
\end{abstract}

Keywords: Biofertilizers, IAA production, phosphate solubilization, PGPR

\section{INTRODUCTION}

Currently, soil management strategies depend on inorganic chemical-based fertilizer and pesticides. These strategies trigger severe threats towards human health, environment, air, and water pollution (Santos et al. 2012; Youssef and Eissa 2014). The toxic agrochemicals contamination to soil and water (e.g., phosphate fertilizer contaminated with heavy metals, pesticides, and herbicides) is of particular concern. These pollutants are generally found in small quantities in water and cannot easily be seen or tasted. Their harmful effects do not manifest in humans for several years but they led to the escalation of deadly diseases (Bhandari 2014). Historically, large amounts of chemicals are useful for agricultural soils as fertilizers and pesticides. They increase heavy metals, such as cadmium $(\mathrm{Cd})$, lead $(\mathrm{Pb})$, and arsenic (As) content in the soil (Atafar et al. 2010). The utilization of microbes is critical as biofertilizers due to their capability to produce healthy food and sustainable crop production.

Biofertilizers are obtained from live or latent cells of plant growth-promoting rhizobacteria (PGPR), such as nitrogen-fixing, phosphate-solubilizing, and indole-3-acetic acid (IAA)-producing microbes. Biofertilizers are applied to seed, soil, or composting area to increase the number of beneficial microorganisms. Moreover, biofertilizers could stimulate the microbial processes to improve the nutrients' availability and assimilation by plants. Biofertilizers play a vital role to decrease the agrochemicals used during crop production (Mahdi et al. 2010; Ramasamy et al. 2020). Biofertilizers could increase the crop yield up to $30 \%$ because of the added nitrogen and phosphorus in the soil and the improvements of soil texture and quality help plants to grow better during drought periods. Biofertilizers also could reduce the effects of harmful organisms in the soil, such as fungi and nematodes, and help plants resist stress better and live longer (Schütz et al. 2018).

PGPR are bacteria that can be found in the rhizosphere and widely used as biofertilizers. PGPR strains employ one or more direct or indirect mechanisms to enhance the growth and health of plants. Some studies reported that PGPR enhances the plant's growth directly through several mechanisms, such as atmospheric nitrogen fixation, minerals solubilization (phosphorus), production of siderophores, and plant growth hormones synthesis (e.g., IAA, gibberellic acid, cytokinin, and ethylene) (Backer et al. 2018). The indirect mechanisms involve the biological control of plant pathogens and deleterious microbes by antibiotics, lytic enzymes, hydrogen cyanide, catalase, and siderophore production. It could also by competition against nutrients and space (Vinayarani and Prakash 2018). These mechanisms can be active simultaneously or independently at the different stages of plant growth (Vinayarani and Prakash 2018).

PGPR was divided into two categories, which are epiphytes PGPR and endophytes PGPR (Singh 2018). The epiphytes PGPR is located in the rhizosphere, on the rhizosphere, or in the space between cells of the root 
cortex, while endophytes are commonly located inside the specialized nodular structures of root cells. Agrobacterium, Arthrobacter, Azotobacter, Azospirillum, Bacillus, Burkholderia, Caulobacter, Chromobacterium, Erwinia, Flavobacterium, Micrococcus, Pseudomonas, and Serratia belongs to the epiphytes group (Ahemad and Kibret 2014). Rhizobiaceae family such as Allorhizobium, Bradyrhizobium, Frankia, and Rhizobium are endophytes group. The endophytes can have a symbiosis with the host plant and fix nitrogen from the air (Bhattacharyya and Jha 2012).

The geographic condition of Kampar makes it a potential land for food crop development. Nevertheless, this region still has declining food production, because the management of land resources is not optimal yet. In addition, the soil types in this region are the less fertile red organosol and yellow podzolic, increasing the difficulty in improving productivity. The development of organic agriculture can be a solution to improve this area's soil fertility and health. Therefore, this current study sought to isolate and investigate the indigenous bacteria from rhizospheric soil at different plant ecosystems in Bangkinang, Kampar, Riau, Sumatra Island. The selected isolates are expected to be developed as biofertilizers that can be used in the local agro-climatic conditions of Kampar, Riau.

\section{MATERIALS AND METHODS}

\section{Soil sampling}

Soil and rhizosphere soil of various plants were collected from four different villages (Ridan Permai, Muara Uwai, Binuang, Pasir Sialang) in Bangkinang district, Kampar, Riau, Indonesia. The soil $\mathrm{pH}$ was ranging from 4.0 to 6.8. During the sample collection, the intact root system was dug out and the rhizospheric soil samples at the vicinity root were collected in polyethylene bags. The collected samples were brought to the laboratory and kept in septic condition at $4^{\circ} \mathrm{C}$ as far as possible for further use.

\section{Phosphate solubilization}

The isolates were evaluated for their phosphatesolubilizing ability on a modified Pikovskaya agar with insoluble tricalcium phosphate (Joe et al. 2018; Majeed et al. 2015). Then, a loop full of each culture was placed on the center of an agar plate and incubated at room temperature $\left(28^{\circ} \mathrm{C}\right)$ for five days. The solubilization zone was evaluated by subtracting the bacterial colony diameter from the diameter of the total zone, as follows.

$$
\text { Solubilisation }=\frac{\text { Colony diameter }+ \text { Halozone diameter }}{\text { Colony diameter }}
$$

The halo zone formation in the bacterial colonies is due to the organic acids and polysaccharides production, which is caused by the activity of phosphatase enzymes by phosphate solubilizing bacterial strains. In theory, the higher SI reflects higher enzyme activity.

\section{Nitrogen fixation}

The initial screening of $\mathrm{N}_{2}$-fixing activity from pure bacterial cultures was evaluated according to the $\mathrm{N}$-free semisolid malate medium (NFB) (Kim et al. 2010). The plates were incubated at room temperature $\left(28^{\circ} \mathrm{C}\right)$ for $24 \mathrm{~h}$, where the color change from pale green to blue qualitatively indicates a positive effect of $\mathrm{N}_{2}$-fixing activity.

\section{Detection of IAA}

Fifty milliliters of nutrient broth $(\mathrm{NB})$ containing $0.1 \%$ DL-tryptophan was inoculated with $500 \mu \mathrm{L}$ of 24-hours-old bacterial cultures with $\mathrm{CFU} \geq 10^{7}$. After that, it was incubated at $30^{\circ} \mathrm{C} \pm 0.1{ }^{\circ} \mathrm{C}$ inside an incubator shaker with $180 \mathrm{rpm}$ shake for $48 \mathrm{~h}$ in a dark condition. The bacterial cultures were centrifuged at $10,000 \mathrm{rpm}, 10$ minutes at $4^{\circ} \mathrm{C}$. The estimation of IAA in the supernatants was conducted by colorimetric assay (Szkop et al. 2012).

One milliliter of supernatant was mixed to $4 \mathrm{~mL}$ of Salkowski reagent. The absorbance of the resultant pink color was determined after 30 minutes of reaction by a UVVIS spectrophotometer (UV mini 1240 Shimadzu, Japan) at $535 \mathrm{~nm}$ wavelength. The appearance of the pink color in the test tubes indicates IAA production based on Ghosh (2019). The IAA production was calculated by a regression equation of the standard curve and the result was presented as $\mu \mathrm{g} / \mathrm{mL}^{-1}$ over the control.

\section{Production of hydrogen cyanide}

The determination of hydrogen cyanide ( $\mathrm{HCN})$ production was conducted according to El-Sayed et al. (2014). The bacterial cultures were streaked on a nutrient agar medium with $4.4 \mathrm{~g} / \mathrm{L}$ of glycine. A Whatman filter paper no. 1 was soaked in $0.5 \%$ picric acid solution (in $2 \%$ sodium carbonate) and then placed into the lid of a plate. The plates were sealed by parafilm and incubated for four days at $30^{\circ} \mathrm{C} \pm 0.1^{\circ} \mathrm{C}$. The development of a light brown to a dark brown color indicated HCN production.

\section{Siderophore production}

The PGPR isolates were assayed to determine the siderophore production on chrome azurole $\mathrm{S}$ agar (CAS) as described by Louden et al. (2011). The agar plates of Chrome azurole $\mathrm{S}$ were prepared and spot-inoculated by bacteria, and then incubated at room temperature $\left(28^{\circ} \mathrm{C}\right)$ for five days. The development of a yellow-orange halo around the colony was considered a positive finding of siderophores.

\section{Catalase activity}

The catalase test was conducted by taking a drop of $3 \%$ hydrogen peroxide and adding it to a 48-hour-old bacterial colony on a clean glass slide, with subsequent mixing. The effervescence result after mixing indicated the catalase activity.

\section{Bacterial molecular analysis}

Selected microbial isolates were further analyzed based on the $16 \mathrm{~S}$ ribosomal RNA gene. Bacterial DNA was extracted by the GES method (Cruaud et al. 2014). The 
DNA amplification was conducted by universal primers for $16 \mathrm{~S}$ rDNA (27F and 1492R) and the polymerase chain reaction (PCR) cycle program was as follows: (1) two minutes at $94^{\circ} \mathrm{C}$; (2) 30 cycles during 30 seconds at $95^{\circ} \mathrm{C}$, 40 seconds at $55^{\circ} \mathrm{C}$, and 30 seconds at $72^{\circ} \mathrm{C}$; and (3) five minutes at $72^{\circ} \mathrm{C}$. The PCR product was sequenced and then analyzed using the Basic Local Alignment Search Tool (https://blast.ncbi.nlm.nih.gov/Blast.cgi) database. This analysis was conducted to determine the homology of the bacterial genetic code to other known species. Multiple sequence alignment of the isolates was performed using a muscle algorithm in the MEGA6 program, and a neighborjoining phylogenetic tree was constructed based on this alignment. The bootstrap method was used as the phylogeny test to test the robustness of the tree.

\section{Effect of PGPR on bok choy (Brassica rapa) seedling growth, in vitro}

Ten seeds of bok choy (Brassica rapa L.) were prepared for each bacteria inoculation to evaluate the effects of isolates on seedling growth. The seed sterilization procedure was performed as the following: the seeds were soaked in $95 \%$ ethanol for three minutes, shaken in a $10 \%$ solution of Chlorox ${ }^{\circledR}$ (The Clorox Company, Oakland, CA, USA) for three minutes, and washed by sterile distilled water for five times. The sterilized seeds were incubated into 12 tubes of NB media containing $1 \times 10^{7}$ colony-forming units $/ \mathrm{mL}$ of 12 bacterial isolates at room temperature for two to four hours. One tube with NB media without bacterial cells was incubated as a control. After two to four hours of incubation, the soaked seeds were placed in sterilized Erlenmeyer flasks containing sterilized filter paper, with 10 seeds/flask. As many as three flasks were used in this study or 30 seeds in total. Seed cultures were incubated for five days at room temperature $\left(28^{\circ} \mathrm{C}\right)$. The percentage of germination and some seedling parameters, such as shoot length $(\mathrm{cm})$ and root length $(\mathrm{cm})$, were calculated.

\section{RESULTS AND DISCUSSIONS}

\section{Isolation of bacteria}

The interaction between PGPR and plants can be unstable, but PGPR with PGP activities may be well adapted in a particular soil environment. Based on this, we isolated and identified PGPRs from different rhizosphere soils according to their multiple mechanisms. The preliminary screening of PGPRs was done under the premise that PGPR may have the abilities of N2-fixing, phosphate solubilization, and IAA production. Forty-two bacterial isolates were successfully isolated from 10 soil samples. All isolates showed PGPR activities at various rates, qualitatively (Table 1). There were 26 bacterial isolates with phosphate-solubilizing properties, seven isolates could produce IAA, and five isolates could fix nitrogen.

Seven bacterial isolates showed IAA-producing abilities according to the pink color formation that occurred following the addition of Salkowski reagent in 48-hours- grown broth. The range of IAA production was from 4.04 to $73.12 \mathrm{ppm}$, where I.4.2 produced the greatest amount of IAA (73.12 ppm) at 48 hours of incubation (Figure 1). IAA production mechanism could be different in each species and strain. It is also affected by culture conditions, growth stage, and substrate availability (Mohite 2013). Isolate I-4.2 was isolated from maize roots and several reports have shown that bacterial isolates from maize possess relatively superior activity. Moreover, isolates from the rhizosphere are more efficient auxin producers than isolates from bulk soil (Sarwar and Kremer 1992).

A total of 26 isolates were evaluated by phosphatesolubilizing ability on Pikovskaya agar. Maximum phosphate solubilization was shown by isolate PK.4.2, followed by PK.10.1 and PK.8.2, with the SI values of $4.33,2.62$, and 2.0, respectively. These three isolates showed the clearest halo zones around their bacterial colonies (Figure 2) that indicated higher phosphatesolubilizing abilities in comparison with other isolates (Table 2). The effectiveness of phosphate-solubilizing microorganisms is mainly dependent on carbon-rich sources from plant roots to produce organic acids for solubilizing soil-bound phosphate (Sharma et al. 2013). The effectiveness of phosphate solubilizing of isolate PK 4.2 ( $\mathrm{SI}=4.33$ ) in the present study could be attributed to the sufficient root exudates. In comparison, the SI values of phosphate-solubilizing fungal strains (Penicillium italicum and Aspergillus niger) were 2.42 and 3.15, respectively (El-Azouni 2008). Phosphate is an essential major nutrient required by plants and most of it is insoluble, so the capability of bacteria to solubilize phosphate and make it available to plants has become an important factor in agricultural management (Alori et al. 2017; Kalayu 2019).

Twelve selected isolates were further investigated through biochemical characterizations and plant growthpromoting assays (Table 2). Among the selected 12 isolates, five were observed to fix nitrogen qualitatively and 10 isolates produced ammonia. It has been reported that ammonia production is another crucial trait of PGPR as it influences plant's growth indirectly. Some studies reported that the positive effect of some diazotrophic bacteria on non-leguminous plant growth and yields might not only be due to nitrogen fixation. Instead, it is caused by other mechanisms that contribute to growth responses observed in non-leguminous plants (Santi et al. 2013).

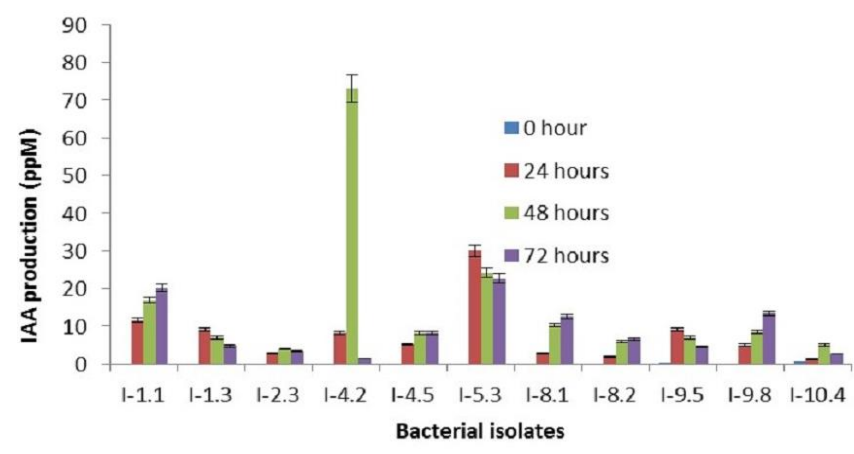

Figure 1. IAA production of eleven bacterial isolates (n- 3, $p$ value $<0.05)$ 
Table 1. Description of the bacterial isolates

\begin{tabular}{|c|c|c|c|}
\hline Sample number & Source of microbial isolate (Soil pH) & Number of isolate & Isolate codes \\
\hline 1 & Rhizosphere soil of grass (pH 5,4) & 6 & I1.1, I1.3, PK1.1, PK1.2, NFB1.1, NFB1.2 \\
\hline 2 & Dugout's soil (pH 5,0) & 1 & I. 2.3 \\
\hline 3 & Soil of Kampar forest $(4,0)$ & 3 & PK3.2, PK3.3, PK3.4 \\
\hline 4 & Rhizosphere soil of Zea mays $(5,9)$ & 6 & I.4.2, I4.5, PK4.1, PK4.2, PK4.3, PK4.4 \\
\hline 5 & Rhizosphere soil of Chili $(6,1)$ & 4 & I5.3, PK 5.1, PK5.2, PK5.3 \\
\hline 6 & Rhizosphere soil of Rubber plant $(5,0)$ & 4 & PK6.1, PK6.2, PK6.3, PK6.4 \\
\hline 7 & Rhizosphere soil of coconut palm $(5,0)$ & 5 & PK7.1, PK7.2, PK7.3, NFB7.1, NFB7.2 \\
\hline 8 & Rhizosphere of Acacia $(5,0)$ & 5 & I8.1, I8.2, PK8.1, PK8.2, PK8.3 \\
\hline 9 & Rhizosphere soil of leafy vegetable $(6,8)$ & 4 & I9.5, I9.8, PK9.1, PK9.2 \\
\hline \multirow[t]{2}{*}{10} & Rhizosphere of rice plant/paddy $(6,2)$ & 4 & I.10.4, PK10.1, PK10.2, NFB10 \\
\hline & Total & 42 & \\
\hline
\end{tabular}

Table 2. Plant growth-promoting activities of bacterial isolates

\begin{tabular}{|c|c|c|c|c|c|c|c|}
\hline Isolate codes & $\begin{array}{c}\text { P solubilization } \\
\text { index (SI) }\end{array}$ & $\mathbf{N}$ fixation & $\begin{array}{c}\text { IAA production } \\
(\mathrm{ppm})\end{array}$ & $\begin{array}{l}\text { Ammonia } \\
\text { production }\end{array}$ & $\begin{array}{c}\text { HCN } \\
\text { production }\end{array}$ & $\begin{array}{l}\text { Catalase } \\
\text { activity }\end{array}$ & Siderophore \\
\hline $\mathrm{I}-4.2$ & - & - & 73.12 & - & +++ & +++ & - \\
\hline $\mathrm{I}-5.3$ & - & - & 30.06 & ++ & +++ & ++ & - \\
\hline $\mathrm{I}-9.8$ & - & - & 13.45 & + & ++ & + & - \\
\hline $\mathrm{I}-1.1$ & - & - & 20.09 & + & +++ & +++ & + \\
\hline PK 4.2 & 4.33 & - & - & +++ & ++ & ++ & +++ \\
\hline PK 10.1 & 2.62 & - & - & ++ & + & +++ & +++ \\
\hline PK 10.2 & 1.90 & - & - & ++ & + & +++ & +++ \\
\hline PK 8.2 & 2.00 & - & - & ++ & +++ & +++ & ++ \\
\hline PK 7.1 & 1.11 & - & - & ++ & +++ & ++ & ++ \\
\hline PK 6.1 & 1.80 & - & - & + & +++ & +++ & ++ \\
\hline N.1.1 & 1.13 & ++ & - & ++ & +++ & +++ & + \\
\hline N.7.1 & - & + & - & - & +++ & +++ & - \\
\hline
\end{tabular}

Notes: + = Positive, - = Negative, + (blue) $\mathrm{N}$ fixing positive, + (orange) ammonia production positive, + (pink) IAA production positive, + (light-dark brown) HCN positive, + (halo zone) siderophore production positive, + (effervescence) catalase positive. All tests were done in duplicate

Table 3. The effect of bacterial isolates inoculation on seedling growth

\begin{tabular}{lccc}
\hline Treatment & $\begin{array}{c}\text { Germination } \\
(\%)\end{array}$ & $\begin{array}{c}\text { Shoot length } \\
(\mathbf{c m})\end{array}$ & $\begin{array}{c}\text { Root length } \\
(\mathbf{c m})\end{array}$ \\
\hline I.4.2 & 90 & $2.53 \mathrm{e}$ & $4.93 \mathrm{ef}$ \\
I.5.3 & 100 & $2.07 \mathrm{~d}$ & $6.11 \mathrm{~g}$ \\
I.9.8 & 80 & $2.07 \mathrm{~d}$ & $3.41 \mathrm{~d}$ \\
I.1.1 & 80 & $2.05 \mathrm{~d}$ & $2.68 \mathrm{c}$ \\
PK.4.2 & 90 & $1.91 \mathrm{~cd}$ & $2.41 \mathrm{c}$ \\
PK.10.1 & 70 & $1.23 \mathrm{~b}$ & $1.07 \mathrm{~b}$ \\
PK.10.2 & 80 & $1.61 \mathrm{c}$ & $5.21 \mathrm{f}$ \\
PK.8.2 & 70 & $1.93 \mathrm{~cd}$ & $4.72 \mathrm{e}$ \\
PK.7.1 & 80 & $1.89 \mathrm{~cd}$ & $5.15 \mathrm{f}$ \\
PK.6.1 & 70 & $2.45 \mathrm{e}$ & $3.21 \mathrm{~d}$ \\
N.1.1 & 90 & $1.70 \mathrm{c}$ & $6.45 \mathrm{~h}$ \\
N.7.1 & 70 & $1.62 \mathrm{c}$ & $4.73 \mathrm{e}$ \\
Control $\left(\mathrm{H}_{2} \mathrm{O}\right)$ & 40 & $1.20 \mathrm{~b}$ & $0.60 \mathrm{a}$ \\
Control $(\mathrm{NB})$ & 45 & $0.83 \mathrm{a}$ & $0.42 \mathrm{a}$ \\
\hline Note: Differ & 40.45
\end{tabular}

Note: Different letters show significant differences between treatments for each cultivar (least significant difference test, $\mathrm{P}<$ $0.05, \mathrm{n}=3$ ).

Eight isolates had a positive result in the siderophore production assay and showed a yellow-orange zone around the colony. Three isolates (PK.4.2, PK.10.1, and PK.10.2) had relatively high production. The capability of rhizobacteria to produce siderophores has been considered in several studies to further study the role of PGPR (Maksimov et al. 2011). Siderophore-producing bacteria make iron available to plants and as these bacteria compete for this element against soil-borne pathogens, they function as biocontrol agents (Ahmed and Holmstrom 2014; Radzki et al. 2013). Growth and siderophore production by PGPR is attributed to organic acids, sugars, amino acids, minerals, enzymes, and various other components of root exudates (Olanrewaju et al. 2017; Pérez-Montaño et al. 2014). In one report, siderophore production depends on the type of carbon source in Pseudomonas sp. (Kumar et al. 2017). Siderophore production is affected by root exudates and there is a possibility that bacteria isolated from different plant roots will also have different siderophore activity.

In the present work, all 12 selected bacterial isolates were positive for $\mathrm{HCN}$ production, which might act as an inducer to plant resistance. $\mathrm{HCN}$ production by rhizobacteria has a critical role in the biological control of pathogens (Rijavec et al. 2016). All 12 isolates were also positive for catalase activity. Bacterial strains with catalase activities will likely have a high resistance to environmental, mechanical, and chemical stress (den Besten et al. 2013). 


\section{Effect of PGPR on bok choy seedling growth}

The performances of all selected bacterial isolates were considered to be the best in terms of plant growthpromoting activities according to their positive PGPR activities (Table 2). The 12 isolates were further screened by testing their effect on the germination and growth of the bok choy seedling. Seed inoculation with PGPR isolates significantly increased seed germination and seedling vigor of bok choy (Table 4). The inoculated seed germination reached $70-100 \%$, while the control only reached $40-45 \%$. The treatment with isolates I 4.2, I 5.3, PK 4.2, and N 1.1 achieved germination of $90-100 \%$. The highest shoot length was observed in seeds treated with isolate I.4.2 (2.53 $\mathrm{cm})$, then PK.6.1 $(2.45 \mathrm{~cm})$, I.5.3 $(2.07 \mathrm{~cm})$, and I.9.8 $(2.07$ $\mathrm{cm})$. Seeds that were inoculated with these four isolates showed shoot length increase by $110 \%, 104 \%$, and $72 \%$, respectively, compared to non-inoculated control. The seedlings' root length was increased significantly after treatments from $78 \%$ to more than $100 \%$ compared to control. Seeds with isolate N.1.1 showed the highest root length $(6.45 \mathrm{~cm})$ similar to isolate I.5.3 $(6.11 \mathrm{~cm})$. From Table 2, we have revealed that these isolates had positive results on $\mathrm{N}$ fixation, ammonia production, catalase, and siderophore production qualitative test. The root length in treatment with isolates PK 10.2, PK 7.1, I 4.2, PK 8.2, and N 7.1 was also good, with a range from 4.72 to $5.21 \mathrm{~cm}$.

It was shown that PGPR inoculation had a significant effect on root and shoot development. The increase in shoot and root length of bok choy seedlings inoculated by IAAproducing bacterial isolates (I 4.2, I 5.3) were observed in this study as well (Table 3). The effect of growth hormoneproducing bacteria inoculation on root and shoot development was also reported by several studies. Boiero et al. 2007 reported that significant shoot growths in maize and rice were promoted by gibberellins-like substances excreted by Azospirillum spp. The PGPR induces changes in external layers of the root cortex due to enhanced divisions of cells in root tips (Baset Mia et al. 2010). The involvement of PGPR formulated cytokinin was also observed in root initiation, cell division, cell enlargement, and increase in root surface area of crop plants through the enhanced formation of lateral and adventitious roots (Werner et al. 2003). In this study, it was shown that Psolubilizing bacteria (PK 10.2, $\mathrm{PK}$ 7.1) and N-fixing (N.1.1) also improved germination and root development. The availability of balanced nutrients, e.g., nitrogen by N2 fixer, Fe by siderophore producers, and phosphate by phosphate solubilizers as well as PGPS producers like ammonia, HCN, and catalase enzyme might have resulted in the significant growth of bok choy seedlings in this study, as observed under in vitro conditions (Table 2).

In the present study, it was shown that there is a correlation between the plant growth-promoting activity of bacteria and the ability to increase germination and seedling vigor. However, there is also an inconsistency observed. Several studies have reported that in vitro screening techniques are useful to choose the potential bacterial strains with multiple plant growth-promoting abilities (Vinayarani and Prakash 2018; Kifle and Laing 2016; Zafar et al. 2012). However, a lack of consistency often exists in correlation among results by in vitro and in vivo (Mutumba et al. 2018; Abbas et al. 2017). The combination of in vitro and in vivo screening techniques is useful for the identification of potential strains. During the experiment, those PGPRs that consistently caused significant increases in the root or shoot development, or both, are selected for further testing in the agricultural field. From the results, it was shown that 5 bacterial isolates (I 4.2, I 5.3, PK 10.2, PK 7.1, N 1.1) had the potential to be further tested in the field as a biofertilizer agent. Of the 5 selected bacterial, two IAA producing bacterial isolates (I.4.2 and I.5.3) showed the best effect on germination and growth of bok choy seedling. Two isolates that showed high activities and significant plant growthpromoting activities were analyzed using $16 \mathrm{~S}$ rDNA sequences.

\section{Sequence identity, similarities, and phylogenetic tree of bacterial isolates}

Two selected isolates (I.4.2, and I.5.3) that showed high activities and significant plant growth-promoting activities were analyzed for their $16 \mathrm{~S}$ rDNA sequences. The phylogenetic trees constructed from the partial $16 \mathrm{~S}$ rDNA sequences of these strains are shown in Figures 3 and 4. Our results revealed that isolates I.4.2 belongs to the genus Sinomonas, while isolate I.5.3 belongs to the genus Arthrobacter.

Table 4. The impact of bacterial isolates inoculation on seedling growth

\begin{tabular}{lcc}
\hline \multicolumn{1}{c}{ Treatment } & Shoot length $(\mathbf{c m})$ & Root length $(\mathbf{c m})$ \\
\hline I.4.2 & $2.53 \mathrm{e}$ & $4.93 \mathrm{ef}$ \\
I.5.3 & $2.07 \mathrm{~d}$ & $6.11 \mathrm{~g}$ \\
I.9.8 & $2.07 \mathrm{~d}$ & $3.41 \mathrm{~d}$ \\
I.1.1 & $2.05 \mathrm{~d}$ & $2.68 \mathrm{c}$ \\
PK.4.2 & $1.91 \mathrm{~cd}$ & $2.41 \mathrm{c}$ \\
PK.10.1 & $1.23 \mathrm{~b}$ & $1.07 \mathrm{~b}$ \\
PK.10.2 & $1.61 \mathrm{c}$ & $5.21 \mathrm{f}$ \\
PK.8.2 & $1.93 \mathrm{~cd}$ & $4.72 \mathrm{e}$ \\
PK.7.1 & $1.89 \mathrm{~cd}$ & $5.15 \mathrm{f}$ \\
PK.6.1 & $2.45 \mathrm{e}$ & $3.21 \mathrm{~d}$ \\
N.1.1 & $1.70 \mathrm{c}$ & $6.45 \mathrm{~h}$ \\
N.7.1 & $1.62 \mathrm{c}$ & $4.73 \mathrm{e}$ \\
Control $\left(\mathrm{H}_{2} \mathrm{O}\right)$ & $1.20 \mathrm{~b}$ & $0.60 \mathrm{a}$ \\
Control $(\mathrm{NB})$ & $0.83 \mathrm{a}$ & $0.42 \mathrm{a}$ \\
\hline
\end{tabular}

Note: Different letters show significant differences between treatments for each cultivar (least significant difference test, $\mathrm{P}<$ $0.05, \mathrm{n}=3)$. 


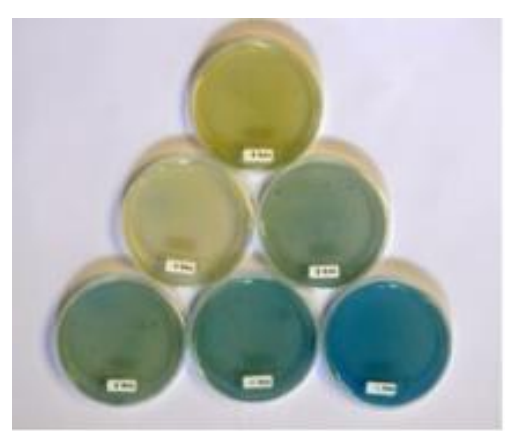

A

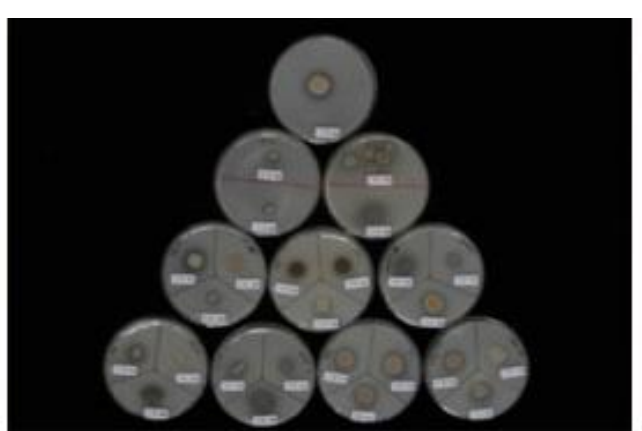

B

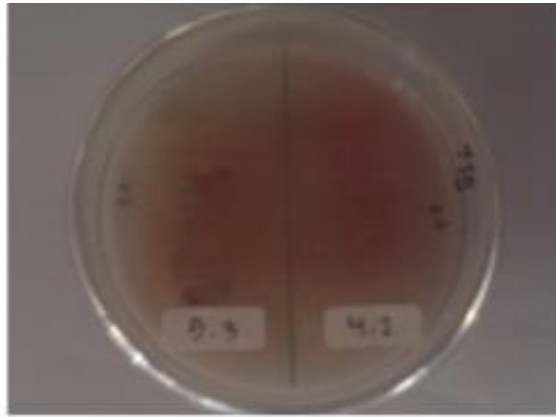

C

Figure 2. Qualitative activities of bacterial isolates, $\mathrm{N}$ fixation, the blue color indicates high activity (A), phosphate solubilization (halo zone) (B), and IAA production (pink color) (C)

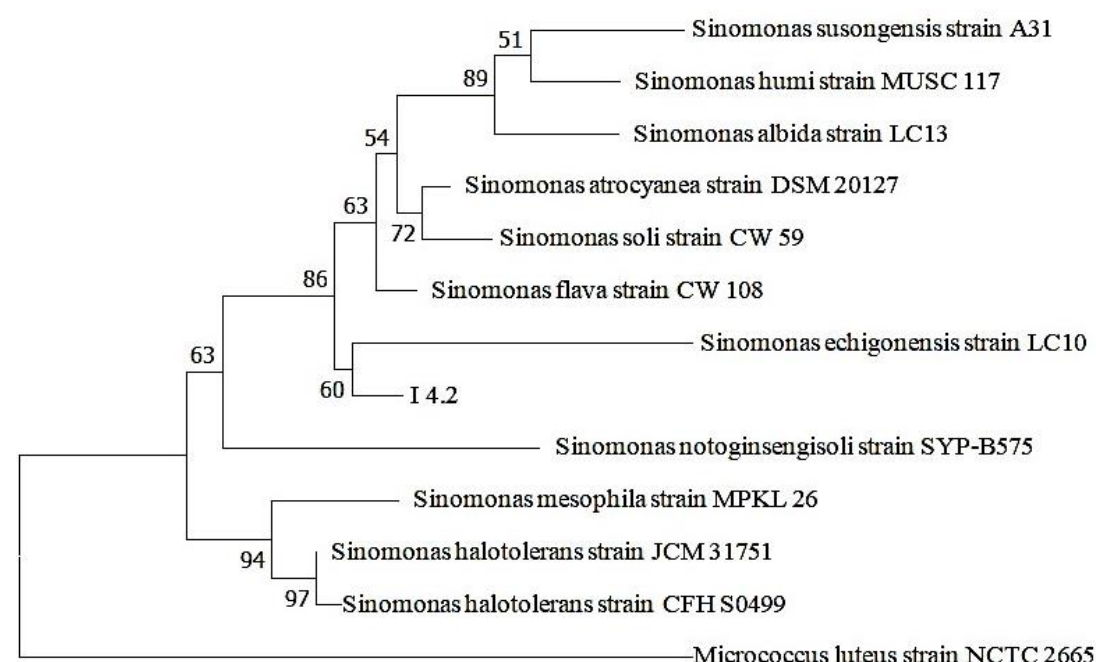

Figure 3. Neighbor-joining tree of isolate I 4.2. S. echigonensis strain LC10 seems to be the closest neighbor of isolate I.4.2.

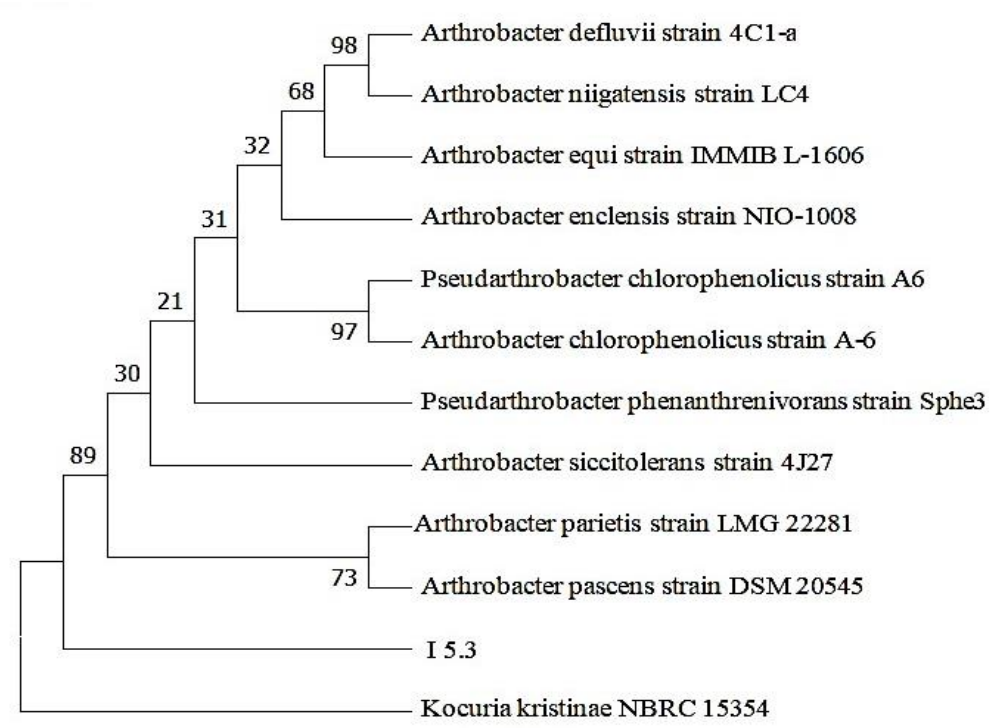

Figure 4. Neighbor-Joining tree of isolate I5.3. The isolate is in the same clade as the Arthrobacter genus. 
Sinomonas (I.4.2) was isolated from maize rhizosphere soil. This isolate could produce IAA, HCN, and catalase enzyme (Table 2). It was reported that Sinomonas was the abundant genera $(13,3 \%)$ identified from Cameroon maize rhizosphere soil (Gylaine et al. 2018). It was reported that Sinomonas is a bacterium that can live in poor environments, such as polluted forest soil and filtration substrates (Zhou et al. 2009; Zhou et al. 2012; Ding et al. 2009). A high level of IAA production is generally produced by the Pseudomonas genus (Xie et al. 1996). Surprisingly, that the results of this study show that the Sinomonas bacteria can produce sufficiently high IAA (73.12 ppm) (Fig 1).

Meanwhile, the Arthrobacter is the most divergent heterotrophic bacterial group of actinobacteria. Arthobacter (I 5.3) isolated from rhizosphere soil of Chili are capable of producing ammonia, HCN, and catalase enzymes, besides the IAA production (Table 2). Arthobacter can be found in places with high environmental stress, such as in saline, dry, polluted, and low-nutrient agricultural soils, where they were found to be useful for plants by protecting them from abiotic stress and by improving plant's nutrition absorption, health, and yield (Shrivastava and Kumar 2015; Bianco and Roberto 2011; Tiwari et al. 2011; Qin et al. 2014).

The existence of these two genera is most likely related to the character of the sampled soils, which was ultisol/redyellow podzolic. Those two bacteria should be further tested as biofertilizer agent candidates in specific locations, especially in areas containing red-yellow podzolic soil.

In conclusion, the effect of plant growth-promoting rhizobia, indigenous to some plant rhizosphere soils from Bangkinang, Kampar, Sumatra Island was observed. Two isolates (Sinomonas flava strain $\mathrm{Cw}$ 108, I.4.2, and Arthrobacter nigatensis, I.5.3) were selected as the potential bacteria strains by multiple plant growthpromoting activities. They had the most optimal effect on the germination and growth of bok choy seedling. These two PGPR isolates can be developed as candidates for biofertilizers to be used in local agro-climatic conditions of Kampar, or red-yellow podzolic soil environments in general.

\section{ACKNOWLEDGEMENTS}

The authors would like to acknowledge the Research Centre for Biology, Indonesian Institute of Sciences in Bogor, Indonesia for its support to this research activity.

\section{REFERENCES}

Abbas A, Jiang D, Fu Y. 2017. Trichoderma Spp. as antagonist of Rhizoctonia solani. J Plant Pathol Microbiol 8: 402. DOI: 10.4172/2157-7471.1000402.

Ahemad M, Kibret M. 2014. Mechanisms and applications of plant growth-promoting rhizobacteria: current perspective. J King Saud Univ Sci 26 (1): 1-20. DOI: 10.1016/j.jksus.2013.05.001

Ahmed E, Holmström SJ. 2014. Siderophores in environmental research: roles and applications. Microb Biotechnol 7 (3): 196-208. DOI: 10.1111/1751-7915.12117.
Alori ET, Glick BR, Babalola OO. 2017. Microbial phosphorus solubilization and its potential for use in sustainable agriculture. Front Microbiol 8: 971. DOI: 10.3389/fmicb.2017.00971.

Atafar Z, Mesdaghinia A, Nouri J, Homaee M, Yunesian M, Ahmadimoghaddam M, Mahvi AH. 2010. Effect of fertilizer application on soil heavy metal concentration. Environ Monit Assess 160 (1-4): 83. DOI: 10.1007/s10661-008-0659-x.

Backer R, Rokem JS, Ilangumaran G, Lamont J, Praslickova D, Ricci E, Subramanian S, Smith DL. 2018. Plant growth-promoting rhizobacteria: Context, mechanisms of action, and roadmap to commercialization of biostimulants for sustainable agriculture. Front Plant Sci 9: 1-17. DOI: 10.3389/fpls.2018.01473.

Baset Mia MA, Shamsuddin ZH, Wahab Z, Marziah M. 2010. Effect of plant growth-promoting rhizobacterial (PGPR) inoculation on growth and nitrogen incorporation of tissue-cultured musa plantlets under nitrogen-free hydroponics condition. Aust J Crop Sci 4 (2): 85-90.

Bhandari G. 2014. An overview of agrochemicals and their effects on environment in Nepal. Appl Ecol Environ Sci 2 (2): 66-73. DOI: 10.12691/aees-2-2-5.

Bhattacharyya PN, Jha DK. 2012. Plant growth-promoting rhizobacteria (PGPR): emergence in agriculture. World J Microbiol Biotechnol 28 (4): 1327-1350. DOI: 10.1007/s11274-011-0979-9

Bianco C, Roberto D. 2011. Soil Bacteria Support and Protect Plants Against Abiotic Stresses. InTech, Rijeka, Croatia.

Boiero L, Perrig D, Masciarelli O, Penna C, Cassan F, Luna V. 2007. Phytohormoneproduction by three strains of Bradyrhizobium japonicum and possible physiological and technological implications. Appl Microbiol Biotechnol 74: 874-880. DOI: 10.1007/s00253-0060731-9

Cruaud P, Vigneron A, Lucchetti-Miganeh C, Ciron PE, CambonBonavita M-A. 2014. Influence of DNA extraction method, 16S rRNA targeted hypervariable regions, and sample origin on microbial diversity detected by 454 pyrosequencing in marine chemosynthetic ecosystems. Appl Environ Microbiol 80 (15): 4626-4639. DOI: 10.1128/AEM.00592-14

den Besten HM, Effraimidou S, Abee T. 2013. Catalase activity as a biomarker for mild-stress-induced robustness in Bacillus weihenstephanensis. Appl Environ Microbiol 79 (1): 57-62. DOI: 10.1128/AEM.02282-12.

Ding L, Hirose T, Yokota A. 2009. Four novel Arthrobacter species isolated from filtration substrate. Int J Syst Evol Microbiol 59 (4): 856-862. DOI: 10.1099/ijs.0.65301-0.

El-Azouni IM. 2008. Effect of phosphate solubilizing fungi on growth and nutrient uptake of soybean (Glycine max L.) plants. J Appl Sci Res 4 (6): 592-598.

El-Sayed WS, Akhkha A, El-Naggar MY, Elbadry M. 2014. In vitro antagonistic activity, plant growth-promoting traits and phylogenetic affiliation of rhizobacteria associated with wild plants grown in arid soil. Front Microbiol 5: 651. DOI: 10.3389/fmicb.2014.00651

Ghosh S. 2019. Changes of edaphic factors due to metabolism of indole acetic acid within the root nodules of Cicer arietinum L. Plant Arch 19 (2): 3151-3154.

Gylaine VTT, Beatrice B, Sacha P, Henri F, Silkke R. 2018. Community structure and plant growth-promoting potential of cultivable bacteria isolated from Cameroon soil. Microbiol Res 214: 47-59. DOI: 10.1016/j.micres.2018.05.008.

Joe MM, Deivraj S, Benson A, Henry AJ, Narendrakumar G. 2018. Soil extract calcium phosphate media for screening of phosphatesolubilizing bacteria. Agric Nat Resour 52 (3): 305-308. DOI: 10.1016/j.anres.2018.09.014

Kalayu G. 2019. Phosphate Solubilizing Microorganisms: Promising Approach as Biofertilizers. Intl J Agron 2019 (4917256): 1-7. DOI: $10.1155 / 2019 / 4917256$.

Kifle MH, Laing MD. 2016. Isolation and screening of bacteria for their diazotrophic potential and their influence on growth promotion of maize seedlings in Greenhouses. Front Plant Sci 6 (1225): 1-8. DOI: 10.3389/fpls.2015.01225

Kim K-Y, Boruah HPK, Kim C-W, Shagol CC, Sa T-M. 2010. Isolation and evaluation of inoculation effect of Azospirillum sp. on growth, colonization and nutrient uptake of crops under greenhouse condition. World Congress of Soil Science, Soil Solutions for a Changing World. Brisbane, Australia, 1-6 August 2010.

Kumar V, Menon S, Agarwal H, Gopalakrishnan D. 2017. Characterization and optimization of bacterium isolated from soil samples for the production of siderophores. Res-Efficient Technol 3 (4): 434-439. DOI: 10.1016/j.reffit.2017.04.004. 
Louden BC, Haarmann D, Lynne AM. 2011. Use of Blue Agar CAS Assay for Siderophore Detection. J Microbiol Biol Educ 12 (1): 51-3. DOI: 10.1128/jmbe.v12i1.249.

Mahdi SS, Hassan GI, Samoon SA, Rather HA, Dar SA, Zehra B. 2010 Bio-fertilizers in organic agriculture. J Phytol 2 (10): 42-54.

Majeed A, Abbasi MK, Hameed S, Imran A, Rahim N. 2015. Isolation and characterization of plant growth-promoting rhizobacteria from wheat rhizosphere and their effect on plant growth promotion. Front Microbiol 6: 198. DOI: 10.3389/fmicb.2015.00198.

Maksimov IV, Abizgil'Dina RR, Pusenkova LI. 2011. Plant growthpromoting rhizobacteria as alternative to chemical crop protectors from pathogens. Appl Biochem Microbiol 47 (4): 333-345. DOI: 10.1134/S0003683811040090.

Mohite B. 2013. Isolation and characterization of indole acetic acid (IAA) producing bacteria from rhizospheric soil and its effect on plant growth. J Soil Sci Plant Nutr 13 (3): 638-649. DOI: 10.4067/S071895162013005000051.

Mutumba FA, Zagal E, Gerding M, Castillo-Rosales D, Paulino L, Schoebitz M. 2018. Plant growth-promoting rhizobacteria for improved water stress tolerance in wheat genotypes. J Soil Sci Plant Nutr 18 (4): 1080-1096. DOI: 10.4067/S0718-95162018005003003.

Olanrewaju OS, Glick BR, Babalola OO. 2017. Mechanisms of action of plant growth-promoting bacteria. World J Microbiol Biotechnol 33 (11): 197. DOI: 10.1007/s11274-017-2364-9.

Pérez-Montaño F, Alías-Villegas C, Bellogín RA, del Cerro P, Espuny MR, Jiménez-Guerrero I, López-Baena FJ, Ollero FJ, Cubo T. 2014. Plant growth promotion in cereal and leguminous agricultural important plants: From microorganism capacities to crop production. Microbiol Res 169 (5-6): 325-336. DOI: 10.1016/j.micres.2013.09.011.

Qin S, Zhang YJ, Yuan B, Xu PY, Xing K, Wang J, Jiang H. 2014 Isolation of ACC deaminase-producing habitat-adapted symbiotic bacteria associated with halophyte Limonium sinense (Girard) Kuntze and evaluating their plant growth-promoting activity under salt stress. Plant Soil 374 (1-2): 753-766. DOI: 10.1007/s11104-013-1918-3.

Radzki W, Gutierrez Mañero FJ, Algar E, Lucas García JA, GarcíaVillaraco A, Ramos Solano B. 2013. Bacterial siderophores efficiently provide iron to iron-starved tomato plants in hydroponics culture. Antonie Leeuwenhoek 104 (3): 321-30. DOI: 10.1007/s10482-013-9954-9.

Ramasamy M, Geetha T, Yuvaraj M. 2020. Role of Biofertilizers in Plant Growth and Soil Health. In: E Rigobelo (eds) Nitrogen Fixation. IntechOpen Limited, London 176-200. DOI: 10.5772/intechopen.87429.

Rijavec T, Lapanje A. 2016. Hydrogen cyanide in the rhizosphere: Not suppressing plant pathogens, but rather regulating availability of phosphate. Front Microbiol 7: 1785. DOI: 10.3389/fmicb.2016.01785.

Santi C, Bogusz D, Franche C. 2013. Biological nitrogen fixation in nonlegume plants. Ann Bot 111 (5): 743-67. DOI: 10.1093/aob/mct048.

Santos VB, Araújo AS, Leite LF, Nunes LA, Melo WJ. 2012. Soil microbial biomass and organic matter fractions during transition from conventional to organic farming systems. Geoderma 170 (2012): 227 231. DOI: $10.1016 /$ j.geoderma.2011.11.007

Sarwar M, Kremer RJ. 1992. Determination of bacterially derived auxins using a microplate method. Lett Appl Microbiol 20: 282-285. DOI: 10.1111/j.1472-765X.1995.tb00446.x
Schütz L, Gattinger A, Meier M, Muller A, Boller T, Mader P, Mathimaran N. 2018. Improving crop yield and nutrient use efficiency via biofertilization-a global meta-analysis. Front Plant Sci 8 (2204): 1-13. DOI: 10.3389/fpls.2017.02204.

Sharma SB, Sayyed RZ, Trivedi MH, Gobi TA. 2013. Phosphate solubilizing microbes: sustainable approach for managing phosphorus deficiency in agricultural soils. Springerplus 2: 587. DOI: 10.1186/2193-1801-2-587.

Shrivastava P, Kumar R. 2015. Soil salinity: A serious environmental issue and plant growth-promoting bacteria as one of the tools for its alleviation. Saud J Biol Sci 22 (2): 123-131. DOI: 10.1016/j.sjbs.2014.12.001.

Singh I. 2018. Plant Growth Promoting Rhizobacteria (PGPR) and their various mechanisms for plant growth enhancement in stressful conditions: A Review. Eur J Biol Res 8: 191-213. DOI: 10.5281/zenodo.1455995.

Szkop M, Sikora P, Orzechowski S. 2012. A novel, simple, and sensitive colorimetric method to determine aromatic amino acid aminotransferase activity using the Salkowski reagent. Folia Microbiol 57 (1): 1-4. DOI: 10.1007/s12223-011-0089-y

Tiwari S, Singh P, Tiwari R, Meena KK, Yandigeri M, Singh DP, Arora DK. 2011. Salt-tolerant rhizobacteria-mediated induced tolerance in wheat (Triticum aestivum) and chemical diversity in rhizosphere enhance plant growth. Biol Fert Soil 47 (8): 907-916. DOI: 10.1007/s00374-011-0598-5

Vinayarani G, Prakash HS. 2018. Growth promoting rhizospheric and endophytic bacteria from Curcuma longa L. as biocontrol agents against rhizome rot and leaf blight diseases. Plant Pathol J 34 (3): 218-235. DOI: 10.5423/PPJ.OA.11.2017.0225

Werner T, Motyka V, Laucou V, Smets R, Van Onckelen H, Schmülling T. 2003. Cytokine indeficient transgenic Arabidopsis plants show multiple developmental alterations indicating opposite functions of cytokinins in the regulation of shoot and root meristem activity. Plant Cell 15: 2532-2550. DOI: 10.1105/tpc.014928

Xie H, Pasternak JJ, Glick BR. 1996. Isolation and characterization of mutants of the plant growth-promoting rhizobacterium Pseudomonas putida GR12-2 that overproduce indoleacetic acid. Curr Microbiol 32: 67-71. DOI: $10.1007 / \mathrm{s} 002849900012$

Youssef MMA, Eissa MFM. 2014. Biofertilizers and their role in management of plant-parasitic nematodes: A review. J Biotechnol Pharm Res 5 (1): 1-6.

Zafar M, Abbasi MK, Khan MA, Khaliq A, Sultan T, Aslam M. 2012. Effect of plant growth-promoting rhizobacteria on growth, nodulation and nutrient accumulation of lentil under controlled conditions. Pedosphere 22 (6): 848-859. DOI: 10.1016/S1002-0160(12)60071-X

Zhou Y, Chen X, Zhang Y, Wang W, Xu J. 2012. Description of Sinomonas soli sp. nov., reclassification of Arthrobacter echigonensis and Arthrobacter albidus (Ding et al. 2009) as Sinomonas echigonensis comb. nov. and Sinomonas albida comb. nov., respectively, and emended description of the genus Sinomonas. Int J Sys Evol Microbiol 62 (4): 764-769. DOI: 10.1099/ijs.0.030361-0

Zhou Y, Wei W, Wang X, Lai R. 2009. Proposal of Sinomonas flava gen. nov., sp. nov., and description of Sinomonas atrocyanea comb. nov. to accommodate Arthrobacter atrocyaneus. Int J Sys Evol Microbiol 59 (2): 259-263. DOI: 10.1099/ijs.0.000695-0 